\title{
The Relationship between Principals' Involvement in Developing Teachers and Students' Academic Performance in Public Secondary Schools in Machakos County, Kenya
}

\author{
John M. Kilonzo (Ph. D Candidate) ${ }^{1} \quad$ David M. Mulwa (Ph.D $)^{2 *} \quad$ Gedion M. Kasivu (Ph.D) ${ }^{1}$ \\ 1.Department of Educational Administration and Planning, South Eastern Kenya University \\ 2.Department of Educational Management and Curriculum Studies, Machakos University
}

\begin{abstract}
Leadership has small but educationally significant indirect influence on students learning outcomes. Conversely, teachers account for significant variance of students' academic performance. Principals' leadership styles can increase teachers' capacities and commitments and thus increase their output which can be reflected in improved students' academic performance. Transformational leadership practices have been shown to increase employee capacities and commitments. The purpose of this study was to establish the relationship between principals' involvement in developing teachers and students' academic performance in public secondary schools in Machakos County, Kenya. This study adopted a descriptive survey design. The study targeted all the 331 principals and 3,006 teachers in public secondary schools in Machakos County. Using simple random sampling, a total of 100 principals were selected and five teachers equally selected from the schools with the sampled principals making a total of 500 teachers. Data collection instruments included questionnaires for principals, questionnaires for teachers and document analysis checklists. Quantitative data was analyzed using both descriptive and inferential statistics. Descriptive statistical tools used were frequencies, percentages, Mean and Standard Deviation while inferential statistical tools such as ANOVA and regression analysis were used to analyze the quantitative Qualitative data was analyzed thematically through content analysis and the responses were presented in narratives. Tables and figures were used to present the analyzed data. The results revealed that there was statistical relationship $(p<0.05)$ between principals involvement in teacher development and students' academic performance which was positive but moderate $(\mathrm{R}=.671)$. Based on the results, it was concluded that transformational leadership practices influence students' academic performance. The study recommends principals to increase transformational leadership practice of developing teachers since it influences students' academic performance.
\end{abstract}

Keywords: Leadership, Leadership style, Transformational Leadership practices, developing teachers

DOI: $10.7176 / \mathrm{JEP} / 11-23-06$

Publication date:August $31^{\text {st }} 2020$

\subsection{Introduction}

Principals are normally held accountable for students' academic performance although most studies have established that they have no direct effect on it. School leaders have indirect influence on students' learning outcomes (Leithwood, Louis, Anderson \&Wahlstrom, 2004). Louis, Dretzke and Wahlstrom(2010)maintain that the impact of schooling on students occurs largely through more sustained relationships that occur in classrooms. In support of this argument, Hattie (2009) through his model confirms that teachers account for about $30 \%$ of the variance of students' academic performance.Leithwood, Patten and Jantzi (2010) claim that school leaders are capable of having significant positive effects on student learning and other important outcomes. Sun and Leithwood (2017) emphasize that school leaders have significant influence on school culture, climate and achievement.

Leadership has been defined differently by different scholars. Watkins and Rikard (1991) defined leadership as the process of influencing the activities of an organized group toward achievement of organizational goals.Kitavi (2014) defines leadership as the interpersonal influence exercised in a situation and directed through the communication process towards the attainment of specific goals of an organization while Dubrin (2010) defines leadership as the ability to inspire confidence and support among followers who are expected to achieve organizational goals. Notably, leadership plays a big role in determining organizational excellence. According to Akpan (2015), leadership is the dynamic force that motivates and coordinates the organization towards attainment of school goals. The success of any organization depends on the leadership style practiced by its leader (Waweru, Orodho \& Getange, 2014). Oluremi (2013) describes leadership style as the manner and approach of providing direction, implementing plans and motivating people while Chandan (2007) describes leadership styles as the patterns of behaviour used by leaders to influence group members and to formulate the strategy and operations of group activities. Dimmock (2013) defines transformational leadership as a leadership approach that causes change in individuals and social systems. In its ideal form, it creates valuable and positive change in the followers with the end goal of developing followers into leaders.

Leithwood and Jantzi (2006) observe that all transformational approaches to leadership share in common the 
fundamental aim of fostering capacity development and higher levels of personal commitment to organizational goals on the part of leaders' followers. The two authors conclude that increased capacities and commitments result in extra effort and greater productivity. Such claims have been validated by empirical evidence. For instance, in the United States, Gkolia, and Koustelios (2014) showed that transformational leadership was positively associated with teachers' job commitment. A study done by Mei and Tsai (2014) on the effect of leadership styles of science teachers on the learning motivation of elementary school students conducted in Changhua County of Taiwan showed that transformational leadership has a significant positive effect on teacher efficiency. A study conducted in Malaysia by Roman, Mey, Don, Daud and Khalid (2015) on the relationship between principals' transformational leadership style and secondary teachers' commitment revealed a significant relationship between principals' transformational leadership and teachers' commitment.

Studies conducted in Kenya have established that transformational leadership leads to improved teacher efficiency, job commitment and academic performance. Chemobo, Kimani, Musiega and Willy (2014) in their study on the effect of transformational leadership styles on teacher performance conducted in public secondary schools in Kakamega, Kenya showed that transformational leadership style had significant positive effect on teacher efficiency. A study done by Kamola (2016) on the influence of head teachers' transformational leadership style on teachers' job commitment conducted in public primary schools established that transformational leadership is positively correlated with teachers' job commitment. A study done by Kitur, Choge and Tanui (2020) on the relationship between principals' transformational leadership style and secondary school students' academic performance conducted in Bomet County, Kenya revealed that transformational leadership had a strong significant relationship with students' academic performance. However, all these studies have employed the general transformation leadership model that has been critiqued for not being school specific (Leadwood \&Jantzi, 2006). This paper addresses this contextual weakness by adopting Leithwood school specific transformational model.

The government of Kenya has singled out education as one of the most important levers that will transform Kenya into a globally competitive country (Muia, 2018). Kenya's Vision 2030 places a lot of emphasis on the link between education and production of competitive human capital (Musangi, Mulwa, Migosi\&Kamau, 2017).A number of factors have been identified to be responsible for low quality of education in Kenya such as weak institutional leadership, low teachers' commitment and motivation (MoE, 2014). To address the problem of weak institutional management, the government of Kenya rolled out diploma in education management training for school heads through Kenya Education Management Institute (KEMI) in order to equip school heads with leadership skills (Ndiga, Mumiukha, Fedha, Ngugi\&Mwalwa, 2014). To address salary and promotion issues which often lead to low commitment and motivation, the Teachers' Service Commission (TSC) signed a Collective Bargaining Agreement (CBA) with teachers unions in 2016 (Jonyo\&Odera, 2017). Even with all these interventions, the quality of education remains low (Kieti, 2017). Perhaps, it is clear that the burden to raise teachers' motivation, capacities and commitment now shifts to the principals. This paper is anchored on transformational leadership theory which advances that transformational leadership can raise employees' capacities and commitments leading to increased output.

In Kenya, there has been an overwhelming concern of students' poor performance in the national examinations as measured by the Kenya Certificate of Secondary Education (KCSE) (Muia, 2018). Examination reports held by Kenya National Examinations Council (KNEC) indicate that a large percentage of students score poor grades between $\mathrm{D}+$ and $\mathrm{E}$ while the quantity of quality grades between $\mathrm{C}+$ and $\mathrm{A}$ has been declining (Kieti, 2017). For a student to qualify for admission to pursue a degree in the university, one needs to have scored a $\mathrm{C}+$ and above. A diploma course would demand not less than a $\mathrm{C}$ (constant) score. Machakos County's performance in KCSE has not been spared by this decline. The County's performance in the KCSE has been below the national average for a long time. There has been a sharp increase of the poor grades (grades D constant and below) while the quality grades $\mathrm{C}+$ and above are getting fewer. The cause for the declining performance is empirically unknown for there has not been sufficient studies to explain this trend.

\subsection{Research Methodology}

This study adopted descriptive survey research design. This design was used because the study was interested in the state of affairs already existing in the field and no variable was to be manipulated. The target population was all the 331 principals and 3,337 teachers in 331 public secondary schools in Machakos County, Kenya. The total target population was therefore 3,668 respondents. Simple random sampling technique was employed to select $30 \%$ of participating schools whose principals were included. Five (5) teachers were randomly selected in all the 100 participating schools making a total sample of 500. In total, the study included a total sample of 600 participants which included 100 principals and 500 teachers. The tools used for data collection were questionnaires for Principals and teachers and also checklists. Questionnaires for principals and teachers used in this study were adapted from Leithwood's Leadership Instrument employed by Rutledge (2010).According to Bowen (2009), document analysis checklists are often used in combination with other methods as a means of triangulation. Bowen (2014) claims that triangulation provides a researcher with a confluence of evidence that breeds credibility. 
Qualitative data from open ended questions and document analysis checklists were transcribed and organized into themes and analyzed through content analysis. The qualitative data was presented in narratives. Quantitative data was analyzed through descriptive and inferential statistics. Descriptive statistics involved calculating frequencies, percentages, Means and standard deviations. Inferential statistics involved ANOVA and Regression Analysis.

\subsection{Results of the Study}

Results from Table 1 show that majority of principals $(\mathrm{M}=4.23$; $\mathrm{SD}=0.73)$ agreed with majority of teachers $(\mathrm{M}$ $=3.97 ; \mathrm{SD}=1.032)$ that they give their teachers individual support to help them improve their teaching practices. Majority of principals $(\mathrm{M}=4.35 ; \mathrm{SD}=0.699)$ agreed with majority of teachers $(\mathrm{M}=4.06 ; \mathrm{SD}=0.931)$ that they encourage teachers to consider new ideas for their teaching. The Principals $(M=4.35 ; \mathrm{SD}=0.96)$ also concur with the teachers $(\mathrm{M}=4.13$; $\mathrm{SD}=0.96)$ that that they model a high level of professional practice. Results also show that majority of principals $(\mathrm{M}=4.35 ; \mathrm{SD}=0.748)$ agreed with majority of teachers $(\mathrm{M}=4.03 ; \mathrm{SD}=1.055)$ that they develop an atmosphere of caring and trust. Results also reveal that majority of principals $(\mathrm{M}=4.41 ; \mathrm{SD}=$ $0.745)$ agreed with majority of teachers $(M=3.83 ; \mathrm{SD}=1.034)$ that they recommend teachers to further their studies. Further, results indicate that majority of principals $(\mathrm{M}=4.19 ; \mathrm{SD}=0.768)$ agreed with majority of teachers $(\mathrm{M}=3.87 ; \mathrm{SD}=0.98)$ that they recommend teachers for promotion. The results confirm that principals were highly practicing transformational leadership practice of developing teachers.

When principals were asked in an open ended question to indicate other ways through which they develop their teachers, majority of them mentioned: facilitating teachers to attend workshops and seminar; benchmarking; facilitating examiners/subject experts to provide coaching; mentoring teachers; providing money for teachers professional development; providing needed teaching and learning resources; changing school norms; challenging teachers to overcome status quo; assisting teachers to overcome challenges. Most of the strategic plans that were reviewed at least mentioned benchmarking, workshops/seminars, teaching and learning resources and infrastructure as some of the targeted strategic activities to be undertaken.

In almost all the minute books analyzed, there was at least an agenda connected to benchmarking, workshops/seminars, and teaching and learning resources, infrastructure and expert coaching that was captured as discussed. This agenda was captured in the minutes of staff meeting in school X: "The principal told the meeting that the school will continue with its policy of facilitating specific classes to benchmark in high performing schools...." In school Y, a minute was captured indicating as, "the principal undertook to ensure all the needed laboratory reagents are bought on timely basis. He further directed HOD science to liase with laboratory technician to identify all the needed resources." Therefore, there was corroborating evidence suggesting principals were providing individual support to teachers.

In order to establish the relationship between principals' involvement in developing teachers and the academic performance of students, a regression analysis was conducted at 0.05 level of significance. Regression results in Table 2 indicate that the relationship between developing teachers and academic performance was positive but moderate $(\mathrm{R}=.675)$. To test whether this model was significant in enabling predictions, the overall model significance was established and analyzed in the ANOVA. The results in Table 3 show that the model identified in Table 2, was indeed significant at alpha level of $.05\left(\mathrm{~F}_{(1,86)}=163.847 ; P \leq .05\right)$. This implies that principals' involvement in developing their teachers could significantly predict the performance of students in public secondary schools of Machakos County.

Further, an analysis of the regression coefficients was conducted to establish the relative strength of prediction of the independent variable upon the dependent variable. Table 4 indicates that principals' involvement in developing their teachers had a significant predictive power on the academic performance of students; $t(87)=$ $12.80 ; \mathrm{p} \leq .05 \beta=.802$. This implies that for every unit increase in the principals developing teachers, the academic performance of students could increase by .802 points.

The objective of this study was to establish the relationship between principals' involvement in developing teachers and students' academic performance. In order to confirm the veracity of this statement, null and alternative hypotheses were formulated as follows:

$\mathrm{H}_{01}$ : There is no statistical significant relationship between principals' involvement in developing teachers and students' academic performance in public secondary schools in Machakos County, Kenya.

$\mathrm{H}_{\mathrm{a} 1}$ : There is statistical significant relationship between principals' involvement in developing teachers and students' academic performance in public secondary schools in Machakos County, Kenya.

Results in Table 4 revealed that there was statistical relationship $(0.011<0.05)$ between developing teachers and students' academic performance. Therefore, the null hypothesis was rejected at 0.05 level of significance and the alternative hypothesis was upheld.

\subsection{Discussion of the Results}

The study findings established that the relationship between developing teachers and academic performance was positive but moderate $(\mathrm{R}=.671)$. Results of the regression coefficient model established that principals 
involvement in developing teachers had a significant predictive power on the students' academic performance; $t$ $(87)=12.80 ; p \leq .05 \beta=.802$. This implied that for every unit increase in the principals developing their teachers, the academic performance of students could increase by .802 points. This means that principals in public secondary schools in Machakos County can improve the academic performance of their schools by increasing the transformational leadership practice of developing their teachers. Further, the study found sufficient evidence to reject the null hypothesis. For instance, the study findings revealed that there was statistical relationship $(0.011<0.05)$ between setting direction and students' academic performance.

The study established that majority of principals in public secondary schools in Machakos County were transformational leaders who were highly practicing transformational leadership practices of developing people consistent with Leithwood Transformational School Leadership Model (Rutledge, 2010). According to Leithwood (2012), this category focuses on leader practices that contribute directly or indirectly to the development of the teachers' dispositions, motivations, and bodies of knowledge and skills which are required to establish and pursue the shared directions of the school. Bush and Middlewood (2013) posit that developing people is the degree to which the leader attends to each follower's needs, acts as a mentor or coach to the follower and listens to the follower's concerns and needs. The three main practices included in developing people are providing intellectual stimulation, providing individualized support, and modeling desirable behavior (Sun \& Leithwood, 2017).

In regard to providing individual support, this study revealed that majority of principals were giving their teachers personal support to improve their teaching. Individualized support refers to the ability of a leader to listen and act as a mentor while treating staff as unique individuals and supporting their professional learning (Sun \&Leithwood, 2017). As cited in Rutledge (2010), Leithwood, Tomlinson, and Genge, (1996) report five basic strategies for fostering individual support which include: equitable, humane, and considerate treatment of one's colleagues; support for the personal, professional development of staff; developing close knowledge of their individual colleagues; recognition of good work and effort; and approaches to change. A transformational school principal keen on improving school performance will offer support for the personal and professional development of staff by providing money for professional development and other needed resources in support of changes agreed on by staff (Leithwood, Jantzi, \&Steinbach, 1999).S/he can also provide coaching for those staff members who need it. Corroborating evidence provided by open ended questions and document analysis checklists confirmed that indeed the principals were providing support to teachers through sponsoring them to attend training workshops and seminars, facilitating benchmarking trips, facilitating expert coaching and providing needed resources.

Under intellectual stimulation, the study results revealed that majority of the principals were encouraging teachers to try new ideas for their teaching. Also, the study established that majority of the principals were recommending their teachers to further their studies. In line with Leithwood Transformational School Model, transformational school principals can foster intellectual simulation by: encouraging staff to try new practices without using pressure; encouraging staff to pursue their own goals for professional learning; helping staff to make personal sense of change and providing the necessary resources to support staff participation in change initiatives (Leithwood, Day, Sammons, Hopkins, \& Harris, 2006).Rutledge, 2010). Encouraging teachers to further their studies is in line with encouraging staff to pursue their own goals for professional learning.

Under modeling desirable professional practices, this study found out that principals model a high level of professional practice. Also, the study further established that majority of principals develop an atmosphere of caring and trust in their school community. Sun and Leithwood (2017) view modeling desirable behavior as the practice of a leader demonstrating integrity and ethical behavior that will leadto respect and trust from followers. A transformational school principal can model desirable behavior by showing general commitment to the school organization, showing commitment to professional growth, enhancing the quality of both group and individual problem-solving processes and reinforcing key values (Rutledge, 2010). Leadership practices related to transformational leader's general commitment to the school organization may take the form of the principal becoming involved in all aspects of school activity, working alongside teachers to plan special events and displaying energy and enthusiasm for own work.

Anderson's (2017) concluded that teachers view principals as role models who inspire a trusting, reassuring environment. Leithwood and Jantzi (2006) observe that a history of working together will build trust. Anderson (2017) stated that teachers are more positive, committed, and intrinsically motivated by administrators using transformational leadership behaviors that inspire trust. According to Mendez-Keegan (2019), one way a school principal can increase intrinsic motivation with teachers is to use transformational leadership practices to create a trusting school environment, whereby teachers intrinsically desire to perform their instructional roles that will help benefit the school.

Specific to studies that have employed the Transformational School Leadership Model, the results of this study disagree with Leithwood and Jantzi (2006) study which showed that transformational leadership practices of developing people were weakly being practiced in schools. However, the findings of this study agree with Rutledge (2010) study that established that transformational leadership practices were highly practiced. This study established that transformational leadership practices are good predictors of academic performance. The findings 
support Kitur, Choge and Tanui (2020) study which revealed that transformational leadership had a strong significant relationship with students' academic performance.

\subsection{Conclusions}

The study findings revealed that principals' transformational practice of developing teachers is a good predictor of academic performance. The study findings also established that principals were highly practicing transformational practice of developing teachers. This means that transformational leadership is desirable for improving students' academic performance. The study findings provide support for continued application of Leithwood School Transformational Leadership Model. This is because the study findings have demonstrated that school specific transformational leadership practices have the promise to improve students' outcomes. The study findings have significant implications to policy makers. The findings can inform policies aimed at improving students' academic outcomes. Principal preparation programs and in-service programs aimed at improving school leadership can include school specific transformational practices in their programs. Although this study established that principals were highly involved in transformational practice of developing teachers, academic performance still remains low. The study results thus confirm that the influence of leadership on academic performance is small. Therefore the contribution of other factors on academic performance such as students' background characteristics, school facilities, staff shortage etc need to be investigated.

\subsection{Possible Future Research Direction}

The purpose of this study was to begin the inquiry into the relationship between principals' involvement in developing teachers and students' academic performance in public secondary schools using Leithwood School Transformational Leadership Model. The positive results from this study of secondary schools provide a basis for continued study on primary schools. The difference could be the unit of analysis.

\section{Reference}

Akpan, C. P. (2015). Work-related variables as correlates of institutional commitment of secondary school teachers in Cross River State, Nigeria. Mediterranean Journal of Social Sciences. 6(3), 315-325.

Anderson, M. (2017). Transformational leadership in education: A review of existing literature. International Social Science Review, 93(1), 1-13.

Chandan J.S. (2007). Leadership and Management.Himachal Pradesh University press. Himachal Pradesh. India.

Chemobo, D.C., Musiega, D., Kimani, C. \& Willy, A. M., (2014). The effect of Transformational Leadership Style on Teacher Efficiency in Public Secondary Schools in Kakamega Central Sub County, Kenya. International Journal for Management Science and Technology,2, (5).

Bowen, G. A. (2009). Document analysis as a qualitative research method. Qualitative Research Journal, 9(2), $27-$ 40.

Bush, M. \&Middlewood, W. E. (2013).Leading and Managing People in Education: London. Sage Publishers.

Dimmock, L.K. (2013). Leadership in Learning-Centred Schools: Cultural Context, Function and Qualities. London. Paul Chapman Publishers.

Dubrin, A. (2010). Leadership Behaviours, Attitudes and Style.Leadership: Research Findings, Practice, and Skills. Mason, $\mathrm{OH}$. Cengage Learning.

Hattie, J. A. C. (2009) A synthesis of over 800 meta-analyses relating to achievements, New York, NY: Routledge

Jonyo, D. O. \&Odera, B. O. (2017). Teacher Management: Emerging issues in Kenya. European Journal of Educational Sciences, 4(1).

Kamola, P. M. (2016) Influence of head teacher's transformational leadership style on teachers' job commitment in public primary schools in Matinyani Sub-County, KituiCounty, Kenya (Unpublished M Ed thesis). Kitui.South Eastern Kenya University.

Kieti, J. M. (2017). An Investigation into Factors Influencing Students' Academic Performance in Public Secondary schools in Matungulu Sub-county, Machakos County (Master's Project).Kitui.South Eastern Kenya University.

Kitavi, M. J. (2014). Influence of head teachers' leadership styles on pupils' performance at Kenya certificate of Primary Education in Matinyani Sub-County, Kitui County Kenya (Unpublished MEd Project). Nairobi. University of Nairobi.

Kitur, K., Choge, J. \&Tanui, E. (2020).Relationship between principals' transformational leadership style and secondary school students' academic performance in Kenya certificate of secondary education in Bomet County, Kenya.Universal Journal of Educational Research, 8(2),402-409.

Leithwood, K., Tomlinson, D., \&Genge, M. (1996).Transformational school leadership.In K.Leithwood et al. (Eds.), International handbook of educational administration (pp. 785-840). Netherlands. Kluwer Academic.

Leithwood, K., Jantzi, D., \& Steinbach, R. (1999).Changing leadership for changing times. Buckingham. UK. Open University Press. 
Leithwood, K., Louis, K. S., Anderson, S. \&Wahlstrom, K. (2004).How leadership influences student learning. New York. The Wallace Foundation.

Leithwood, K., \&Jantzi, D. (2006).The effects of transformational leadership on organizational conditions and student engagement with school. Journal of Educational Administration, 38 (2), 112-12.

Leithwood, K., Day, C., Sammons, P., Hopkins, D., \& Harris, A. (2006).Successful school leadership: What is it and how it influences pupil learning. A report to the Department for Education and Skills.

Leithwood, K., Patten, S., \&Jantzi, D. (2010). Testing a concept of how school leadership influences student learning. Educational Administration Quarterly, 46(5), 671-706.

Leithwood, K. (2012). Core practices: The four essential components of the leaders' repertoire. In K. Leadwood $\&$ K. S. Louis (Eds.), Linking leadership to student learning (pp. 57-67). San Francisco, CA

Louis, K. S., Dretzke, B. and Wahlstrom, K. (2010) 'How does leadership affect student achievement? Results from a national US survey'. School Effectiveness and School Improvement, 21, 315-336

Mei, H. L. \& Tsai, F. C. (2014). The effects of the leadership style on the learning motivation of students in elementary schools. Journal of Service Science and Management retrieved from http://dx.doi.org/10.4236/jssm.2014.71001

Mendez-Keegan, M. (2019).Transformational leadership practices and student achievement in diverse urban elementary schools (PhD Thesis). Waden University.

Ministry of Education, (2014).Leading and managing to achieve results. Nairobi. KEMI.

Muia, P. N. (2018). Influence of principals' transformational leadership practices on academic performance in Kenya Certificate of Secondary Education in Mbooni West Sub County, Kenya (Unpublished Phd Thesis). Nairobi. University of Nairobi..

Musangi, S. S., Mulwa, D. M., Migosi, J. \&Kamau, L. M. (2017).Influence of school-based factors on educational wastage in public secondary schools in Machakos County, Kenya. International Journal of Humanities and Social Science, (7)1, 257-261.

Ndiga, B., Mumiukha, C., Fedha F., Ngugi, M. \&Mwalwa, S. (2014). Principals’ Transformational Leadership Skills in Public Secondary Schools: A Case of Teachers' and Students' Perceptions and Academic Achievement in Nairobi County, Kenya. American Journal of Educational Research.2 (9).

Nderitu, A. W. (2012) Effects of principals' transformational leadership characteristics on students' performance in secondary schools in Nairobi County (Unpublished PhD thesis). Nairobi. University of Nairobi.

Oluremi, O. F. (2013). Enhancing educational effectiveness in Nigeria through teachers' professional development.European Scientific Institute.Retrieved from http:dx.doi.org/10.9044/esj

Sun, J., \&Leithwood, K. (2017).Calculating the power of alternative choices by school leaders for improving student achievement. School Leadership \& Management, 37, 80-93.

Raman, A., Mey, H. C., Don, Y., Daud, Y. \& Khalid, R. (2015).Relationship between principals' transformational leadership style and secondary school teachers' commitment .Asian Social Science, 11(15).

Rutledge, R. N. (2010). The Effects of Transformational Leadership on Academic Optimism within Elementary Schools (Unpublished PhD thesis) University of Alabama. Tuscaloosa, Alabama

Watkins, D. L., \&Rikard, G. L. (1991). Perceptions of leader behaviors of athletic directors: Implications for change. Physical Educator, 48(1), 2-6.

Waweru, P. N., Orodho, J. A., \&Getange, K, N. (2014). Progress towards Attainment of Education for All (EFA) Among Nomadic Pastoralists: How do we dismantle the gender differential jinx in Mandera County, Kenya. Journal of Humanities and Social Sciences (IOSR-JHSS). Retrieved from www.iosrjournals.org

Table 1: Principals' Leadership Practices of Developing Teachers (Principals' \& Teachers' View Points)

\begin{tabular}{|c|c|c|c|c|}
\hline \multirow[t]{2}{*}{ Statement } & \multicolumn{2}{|l|}{ Principals } & \multicolumn{2}{|c|}{ Teachers } \\
\hline & $\mathbf{M}$ & SD & $\mathbf{M}$ & SD \\
\hline $\begin{array}{l}\text { I/the principal give }(s) \text { teachers individual support to help them } \\
\text { improve their teaching practices }\end{array}$ & 4.23 & 0.73 & 3.97 & 1.032 \\
\hline $\begin{array}{l}\text { I/the principal encourage(s) teachers to consider new ideas for their } \\
\text { teaching }\end{array}$ & 4.35 & 0.699 & 4.06 & 0.931 \\
\hline I/the principal model(s) a high level of professional practice & 4.35 & 0.732 & 4.13 & 0.96 \\
\hline I/the principal develop(s) an atmosphere of caring and trust & 4.35 & 0.748 & 4.03 & 1.055 \\
\hline I/the principal recommend(s) teachers to further their studies & 4.19 & 0.768 & 3.83 & 1.034 \\
\hline I/the principal recommend(s) teachers for promotion & 4.34 & 0.761 & 3.87 & 0.98 \\
\hline
\end{tabular}


Table 2: Influence of Principals' involvement in Developing Teachers on Students' Academic Performance Model Summary

\begin{tabular}{|c|c|c|c|c|}
\hline Model & $\mathrm{R}$ & R Square & Adjusted R Square & $\begin{array}{l}\text { Std. Error of the } \\
\text { Estimate }\end{array}$ \\
\hline 1 & $.821^{\mathrm{a}}$ & .675 & .671 & .34488 \\
\hline
\end{tabular}

Table 3: ANOVA for Principals' involvement in Developing Teachers and Academic Performance

\begin{tabular}{llrrrrr}
\hline Model & & Sum of Squares & df & Mean Square & F & Sig. \\
\hline \multirow{2}{*}{1} & Regression & 19.488 & 1 & 19.488 & 163.847 & $.000^{\mathrm{b}}$ \\
& Residual & 9.396 & 86 & .119 & & \\
\hline
\end{tabular}

a. Dependent Variable: Academic Performance

b. Predictors: (Constant), Developing Teachers

Table 4: Regression Coefficients of influence of Principals' involvement in Developing Teachers on Students' Academic Performance

\begin{tabular}{llrrrrr}
\hline \multirow{2}{*}{ Model } & & \multicolumn{2}{c}{ Unstandardized } \\
& & \multicolumn{2}{c}{$\begin{array}{c}\text { Standardized } \\
\text { Coefficients }\end{array}$} & \multicolumn{2}{c}{ Hypothesis Testing } \\
\hline \multirow{2}{*}{1} & & B & Std. Error & Beta & $\mathrm{t}$ & Sig. \\
& (Constant) & .719 & .275 & & 2.620 & .011 \\
& Developing Teachers & .802 & .063 & .821 & 12.800 & .000 \\
\hline
\end{tabular}

a. Dependent Variable: Academic Performance 